\title{
20 YEARS OF EUROPEAN FUNDS' MANAGEMENT - WHAT WE HAVE LEARNED AND WHAT IS TO DO NEXT? A PRACTITIONER'S PERSPECTIVE
}

\author{
E. MARCU, M-S. CORDUNEANU
}

\section{Elena MARCU}

Lecturer PhD.

Faculty of Juridical and Administrative Sciences, Agora University of Oradea, Romania

*Correspondence: Elena Marcu, Agora University of Oradea, 8 Piaţa Tineretului St., Oradea, Romania

Email: elena.sferlea@cjbihor.ro

\section{Marius Ștefan CORDUNEANU}

Student, Faculty of Juridical and Administrative Sciences, specialization Law Agora University of Oradea

\section{ABSTRACT:}

The management of European funds was part of the public agenda, in a consistent manner, for the past 15 to 20 years. Although visible progress has been made since the moment Romania started to access pre-accession funds (Phare, ISPA, SAPARD), to date, with direct effects on the economic growth, the efficiency in implementing it suffered a lot due to the political spectrum intervention, the human resource involved, the volatile administrative framework or even due to the influence, sometimes unwelcomed, of the private sector. The present material tries to unveil some of the causes that affected the implementation of European projects, and also to offer a range of solutions for a better management of it, taking into consideration the fact that the new programming period, 2021-2027, is at our doorstep.

KEY WORDS: European funds; management; political spectrum; human resource; absorption.

\section{INTRODUCTION}

Although Romania officially joined the European Union on the $1^{\text {st }}$ of January 2007, the European path of the country started much earlier, the most important moment from the perspective of European funds management taking place in February 2000: during the EU Council for General Affairs meeting, for the launching of the Intergovernmental Conference, the official accession negotiations are opened, which meant that from that moment on, Romania had the opportunity to access European funding, through pre-accession programmes ${ }^{1}$.

Hereinafter, we will make a short presentation of Romania's situation at that moment: a disastrous economic situation, marked by dubious privatizations, political and institutional instability, a never-ending provisional state (the so called "transitional period"), of general uncertainty at all levels of society. The Progress Reports issued by the European Commission mentioned, in not so optimistic terms, the stage of implementation of the necessary measures to be taken in order to join the EU, the administrative framework being one of the main issues to be tackled at that moment, as it is stated into the 2003 Report: "Although Romania

\footnotetext{
${ }^{1}$ For more details, please consult https://europa.eu/rapid/press-release_PRES-00-32_en.htm, accessed on 12.09.2019.
} 


\section{Elena Marcu, Marius Ștefan Corduneanu}

continues to make progress in what concerns the adoption and implementation of the <acquis (communautaire)>, there is still a great distance between the commitments made during the negotiations for accession and Romania's administrative capacity to fulfill it. Also, in the case of many priorities set into the revised Accession Partnership, the legislative alignment must continue" 2 . That was the framework in which Romania had to create the institutional structures, had to train its human resource etc, in order to manage to implement the preaccession projects (on Phare, ISPA and SAPARD financing Programmes). With a lot of help from many technical assistance projects, Romania managed to create, in a quite reasonable timeframe, the institutional framework for managing European funds, at least from a formal point of view. From a broader perspective, though, the image didn't look as good, many shades appearing on that apparently clear picture...

And these shades were quite a few. Maybe the most important aspect is that, at that moment, Romania had a public administration centered on a communist model of managing the community problems, an administration trapped in a certain way of thinking and applying the concepts, completely hanged to the political spectrum, which tried to define itself in the new geo-political context, a context that required adaptations in order to join the EU and NATO. And many adjustments were needed in this respect. As a young (and probably naïve) master student, taking an MBA in Public Sector Management at Birmingham University (United Kingdom), I decided to tackle in my final paper the applicability of the "New Public Management" model in that day Romania. This management system, at that moment completely adopted only in some of the Anglo-Saxon administrative systems, promised a lot: a flexible administration, with less strict hierarchical leyers, with a more degree of implication of the private sector into the community problems, which was seen as a partner in tackling it, with clear and well-defined performance indicators of the public sector etc. It represented everything that we didn't have and we wanted to have, at least from a lip service. From the start of the documenting process for the paper till the end of it, my enthusiasm was gradually tempered, the final conclusion being that, for the moment, Romania was not ready to implement the New Public Management, due to the cultural conflict between the existing administration and the new practice models, so generous at least theoretically. Less than two years later, I was working in the Romanian central public administration, managing preaccession European funds (Phare), confronting the realities of the public administration, which looked very similar with what I have found, from a theoretical perspective, during the documentation of my final paper: an administration less opened to new models, hanged to the political spectrum, bearing a low flexibility and trapped in pre-defined patterns.

\section{A PATH PAVED WITH OBSTACLES. WHAT WE HAVE LEARNED?}

Although, changes were made, and not just a few, affecting the system in a positive way, starting with that period of time. Around the moment when Romania has joined the EU, a group of well- trained professionals existed in the area of management of European funds (especially trained through technical assistance projects), in the central and also the local administration. That personnel had a good understanding of project management, both in theory and practice (for many people, this could sound elementary, but at that moment, it was a huge step forward, compared to the previous period of time, when the annual planning prevailed over the multiannual strategic planning); it was predominantly young, more prone to adopt a new way of thinking (we could say that around the year when Romania has joined the EU and in the following years, more than $75 \%$ of the human resource consisted of youngsters up to 35 years old, proficient in English or other foreign language, having completed long-term specialization courses or even long-term studies abroad); it was enthusiastic, feeling that the things started to move, after very hard times in terms of economy

\footnotetext{
${ }^{2}$ European Commission - 2003. Raport periodic privind progresele inregistrate de Romania pe calea aderarii, p. 137, http://www.anr.gov.ro/docs/rapoarte/Raport_periodic_privind_progresele_Romaniei_pe calea aderarii 183.pdf, accessed on 16.09.2019.
} 
20 YEARS OF EUROPEAN FUNDS' MANAGEMENT - WHAT WE HAVE

LEARNED AND WHAT IS TO DO NEXT? A PRACTITIONER'S PERSPECTIVE

and social issues and the European funds are part of the solution for developing the country and we can all contribute to that goal.

At the same time with the institutional establishment of the stakeholders, with the personnel training, with a better understanding of project management came also situations that will at the end limit the progresses made in that area, with effects that are still valid to this day: the political spectrum interference in the management of European funds or the siphoning of the European funds by bogus private consultancy companies and other beneficiaries of the European funding.

Some additions are necessary in this respect, mainly regarding the involvement of politics and politicians in the area of European funded projects. First of all, we must say that the influence of politics within the management of projects, irrespective of the source of financing, is, to a point, normal and necessary. After all, the politicians define the development strategy on sectoral areas, including that of an administrative unit, the politicians have the power to decide, they can assure the financing for any course of action, they set the priorities. The problem appears when the priorities, for example, are set based on private interests, personal or of a group of interests, rather than the general wellbeing of the community, for economic reasons or when it interferes with the human resource directly involved in the management of projects. Too often, some initiatives are financed due to the personal interests of the political leadership and less based on the real needs of the community. Also, in many cases, the influence of the political spectrum is used in order to press and coerce the human resource involved in the management of European funds, with direct effects on the efficiency of the administrative capacity: with every political change, almost automatically the high level of the administration is changed (general directors, directors, etc), and also the medium level is affected (head of office for example), a fact that is seriously affecting the continuity and, thus, the effectiveness of the administrative actions. Unfortunately, this way of involvement into the inner life of the administration continues to this day, with destructive effects over the administrative capacity.

The same as in the case of the political involvement, the influence of the consultancy companies has both positive and negative effects on the management of European funded projects. Although it is absolutely clear that they are useful and, if they act in a correct and efficient manner, constitute an undeniable help for the administration and the private sector, in the same time they can represent a disruptive factor if using their knowledge in other ways that they should do. Many cases had come to the public attention, especially through media, presenting politicians that went hand in hand with bogus consultancy companies or even cases when politicians acted both as administrators of private companies and of the public goods...As we have said above, unfortunately, these situations are as real today as they were 10 years ago, affecting on long term the implementation of European funded projects, affecting the absorption rate and maintaining a way of thinking which collides with the idea of proper and sound management.

What is even more disturbing from the perspective of administrative efficiency is the fact that all these deficiencies were known and accepted by the stakeholders involved, and not only those presented above, but many more, as the conclusions of the performance audit report of the Court of Accounts of Romania for the period 2007-2012 was presenting. Thus, the report reveals a: ,Low interest of the majority of public institutions in accesing European funds, in the audited period (2007 - 2012)", "defective budgetary programming of public funds neccesary for implementing the projects of the credit principals acting as beneficiaries", "no control or analysis was made over the budget execution regarding the use of funds awarded from the public budget for accessing non-reimbursable European funds at the credit principals, at local or central level, by the structures having atributions in this regard within the Ministry of Finance", "the lack of qualified personnel, having experience in 
the area of European funds, staff turnover, lack of vision in some situations in efficiently achieving the objectives of the program". ${ }^{3}$

But, after all, to get back to the title of this article, what we have achieved in the past 20 years of managing European funds? A lot, quite a lot. Although it sounds to be basic and self-evident, we could say that first of all, we learned how to manage European funded projects. Also, we learned that is better to develop useful projects, with an impact over the society or community, not just projects that are designed especially for some persons or entities in order to gain some financial advantages. It became clear over time that a project which is made considering the last aspect is hard to implement, leading to financial corrections on it, to the extent that the financial benefit of the financing is nullified (this aspect was learned by many, but this practice still exists today, in order to favor some public or private actors). We learned that the management of projects is not a game, that fraud and the conflict of interest are serious matters, being punished by law at the end, as criminal offences. Maybe that's the most important aspect that we have assimilated, since it defines a change in our mindset: if after the Romanian Revolution of 1989 it became quite common to think that everything is permitted, including "stealing" in different ways (and the ones who were not letting you do so were labeled as communists), now, with the help of European funded projects, the concepts of accountability and responsibility are valued again.

\section{WHAT IS TO DO NEXT? A SET OF PROPOSALS}

At this moment, we could say that we reached "adulthood" (or at least an end of childhood) in what concerns this area of expertise. But there are still a lot of things to do, at all levels (in some cases though it is better for some things not to be done in fact...)

First of all, the influence of the politics into the project management should be limited to some extent, by eliminating the possibility of replacing/firing the personnel involved in the management of European funded projects at every political change, at central or local level. (the new Administrative Code, adopted through Emergency Government Decision no. 57/2019, has already missed the opportunity to do something in this respect, the perspectives regarding it being dissuasive considering this); also, by limiting the possibility to interfere with the implementation of some strategic documents (as an example, see the so-called Masterplan for Transport, a document that was designed to be a long-term planning strategic sheet, but in fact it is changed by every transport minister, and they were quite a few in the past 8-9 years, due to local and electoral considerations $)^{4}$; and maybe most of all, by limiting the use of European funds as an electoral tool, used just for marketing and ignored in the rest of the occasions, as a mean of community development.

Secondly, the legislative changes in this particular area should be restricted to applying the European Regulations and Directives, without producing continuous malfunctions into the system. This aspect is mainly related to the permanent changes that affect the financial management of the project, where the numerous adjustments of the Law no 227/2015 adopting Fiscal Code transform the implementation of European funded projects into a never-ending saga, but one which never ends well for the beneficiaries. This predictability is requested by everybody, but especially by the private sector, but the future is uncertain the same as in the rest of the presented cases.

\footnotetext{
${ }^{3}$ Curtea de Conturi a Romaniei - RAPORT DE AUDIT "AUDITUL PERFORMANȚEI UTILIZĂRII FONDURILOR ALOCATE DE LA BUGETUL DE STAT PENTRU DERULAREA PROGRAMELOR SAU PROIECTELOR FINANȚATE PRIN FONDURILE EXTERNE NERAMBURSABILE pentru perioada intermediară 2007-2012", $\quad$ Bucuresti, 2013, pp. 16-25, http://www.curteadeconturi.ro/Publicatii/Raport_audit_performanta_FEN_2007-2012.pdf, $\quad$ accessed on 18.09.2019.

${ }^{4}$ Curs de Guvernare - editie online, https://cursdeguvernare.ro/politizarea-infrastructurii-distruge-si-noulmaster-plan-pe-transporturi.html, accessed on 12.09.2019.
} 
Even more, a strict control of the activity of consultancy companies acting in this field of expertise should be exerted, by using a system of credentials and thus of supervision, so the cases in which a company with 2-3 employees manages projects of billions of Euros will not exist anymore. Without affecting the free market and the competition, this system will contain the activity of the bogus companies that are siphoning the public money for more than 20 years.

We should not forget the importance of creating, maintaining and developing a human resource that is capable, involved, determined and conscious of the important mission that it has. The involvement of politics to a large extend in the change of personnel creates not just malfunctions of the administrative system, but also a deception of the human resource, which is feeling constantly under pressure. The continuous training of staff, assuring the stability of the job, the involvement of all layers of decision into the strategic planning should be priorities not only for the future, but starting now.

Moreover, we should take into consideration the fact that these projects, although referred in the day-to-day speech as being "financed through European funds", are in fact cofinanced from the EU budget. Based on the development region, the Operational Programme, the type of beneficiary, the contracting conditions etc, this co-financing varies from $98 \%$ to $30-40 \%$, the rest being in the responsibility of the state or of the direct beneficiary of the financing. Thus, conditions should be created for the beneficiary, either a public or private entity, in order to be able to ensure this complementary financing. Although some measures were taken in this respect, from the central level, like the establishment of the National Fund for Guaranteeing the Credit for SMEs since 2001, these were able to solve the problem of financing for the beneficiaries only to a certain degree, by reducing the bank risk and thus lowering the bank fee ${ }^{5}$. The financial difficulties that the small, rural, local administrations ${ }^{6}$ or the NGOs are facing cannot be solved through last-minute or discretionary measures, like allocation of funds from the Government's Reserve Fund, based on who-knows criteria ${ }^{7}$, or through the allocations, the same as shady and politically biased, of the County Councils to city halls (the examples in this respect are so many, unfortunately, but we decided to choose only one not to overcrowd this material $)^{8}$. Also, the actions taken regarding the indebtedness rate of the city halls to the State Treasury, approved through Government Decision no 8/2018, as a last resort measure, gave just a breath of air to the public administrations suffocated by expenses $^{9}$. It is necessary to create a uniform, coherent, correct and based on clear criteria system of supporting the public administrations in need which require support for implementing major projects, that can prove useful for the community.

For sure, there are many other things to be done, but since the management and control system reached a certain maturity, with all the shortcomings, maybe is not a good idea

\footnotetext{
${ }^{5}$ Eugen Staicu, Fondul Național de Garantare a Creditelor pentru IMM-uri: o soluţie?, in Legestart, online edition, $27^{\text {th }}$ of February 2017, https://legestart.ro/fondul-national-de-garantare-creditelor-pentru-imm-uri-osolutie/, accessed on 25.09.2019.

${ }^{6}$ In the context of the approval of Emergency Government Decision no 46/2013, regarding the financial crisis and insolvency of public administration units, more than 2000 city halls cannot pay their current expenses from their own budget.

${ }^{7}$ Anca Simina, Ultima împărţire pe şest a milioanelor din Fondul de Rezervă al lui Ponta spre primării şi biserici. Cum a cheltuit Guvernul in 2013 „, bugetul paralel”, in Gandul, online edition, $12^{\text {th }}$ of December 2013, https://www.gandul.info/politica/ultima-impartire-pe-sest-a-milioanelor-din-fondul-de-rezerva-al-lui-ponta-spreprimarii-si-biserici-cum-a-cheltuit-guvernul-in-2013-bugetul-paralel-11756982, accessed on 25.09.2019.

${ }^{8}$ Ciprian Vancea, Discutii aprinse despre cum se aloca in CJ banii pentru primarii, in Graiul Maramuresului, online edition, $8^{\text {th }}$ of August 2017, http://www.graiul.ro/2017/08/08/discutii-aprinse-despre-cum-se-aloca-cjbanii-catre-primarii/, accessed on 24.09.2019.

${ }^{9}$ Ovidiu Barbulescu, Guvernul majorează limita de îndatorare a primăriilor și permite împrumuturi de la Trezorerie, in plafonul de 800 milioane lei, pentru proiecte din fonduri europene, www.profit.ro, $23^{\text {rd }}$ of August 2018, https://www.profit.ro/insider/banci-asigurari/guvernul-majoreaza-limita-de-indatorare-a-primariilor-sipermite-imprumuturi-de-la-trezorerie-in-plafonul-de-800-milioane-lei-pentru-proiecte-din-fonduri-europene$\underline{18363474}$, accessed on 24.09.2019.
} 
to start everything from scratch and make radical transformations of the system. In this way, the implementation tools that the personnel involved in the managing of European funds used in the past, which become common knowledge over time, will be better used also in the future, due to the routine of applying it. Anyhow, the new programming period 2021-2027 will bring many changes to the current situation, as the drafts of the European Regulations regarding European funds look at this moment ${ }^{10}$, fact that will again disrupt the management system of project's implementation.

\section{INSTEAD OF CONCLUSIONS}

In order to conclude in a positive manner, we would like to point out an information already presented in the official statistics: Romania's GDP almost doubled since the moment it joined the EU in 2007 (see Graphics) and this happened also due to the use of European funds ${ }^{11}$. We have no reason to doubt that this growth will continue having this important financial support. Even if at this moment the absorption rate is approximately $30 \%{ }^{12}$ (out of which a good part represents direct payments to farmers, the so-called subsidies), just a little below the European average of approximately 33\%, with minimal responsibility and involvement we can assure a sustainable growth of it, and the best part is that is only up to us to do so.

DISCLAIMER: This article does not present the point of view of MRDPA, of the Managing Authority for Interreg V-A Romania-Hungary Programme or any other organization involved in the management of the Programme, expressing only personal considerations.

\section{BIBLIOGRAPHY}

Barbulescu, Ovidiu, Guvernul majorează limita de îndatorare a primăriilor și permite imprumuturi de la Trezorerie, in plafonul de 800 milioane lei, pentru proiecte din fonduri europene, www.profit.ro, $23^{\text {rd }}$ of August 2018, https://www.profit.ro/insider/banciasigurari/guvernul-majoreaza-limita-de-indatorare-a-primariilor-si-permite-imprumuturi-de-

la-trezorerie-in-plafonul-de-800-milioane-lei-pentru-proiecte-din-fonduri-europene-18363474 Curs de Guvernare -online edition, https://cursdeguvernare.ro/politizarea-infrastructuriidistruge-si-noul-master-plan-pe-transporturi.html

Curtea de Conturi a Romaniei, RAPORT DE AUDIT "AUDITUL PERFORMANȚEI UTILIZĂRII FONDURILOR ALOCATE DE LA BUGETUL DE STAT PENTRU DERULAREA PROGRAMELOR SAU PROIECTELOR FINANȚATE PRIN FONDURILE EXTERNE NERAMBURSABILE pentru perioada intermediară 2007-2012", Bucuresti, 2013 EUR- Lex - https://eur-lex.europa.eu/legal-content/RO/ALL/?uri=CELEX\%3A52018PC0322 European Commission - 2003. Raport periodic privind progresele inregistrate de Romania pe calea aderarii, http://www.anr.gov.ro/docs/rapoarte/Raport_periodic_privind_progresele_Romaniei_pe_cale a_aderarii_183.pdf

Finantare.ro - https://www.finantare.ro/roxana-manzatu-romania-a-atras-95-miliarde-de-eurodin-fonduri-europene-rata-de-absorbtie-fiind-de-30.html

Rudnitchi, Constantin, Efectele fondurilor europene asupra economiei, in RFI Romania, online edition, $22^{\text {nd }}$ of February 2016, https://www.rfi.ro/economia-reala-84918-efectelefondurilor-europene-asupra-economiei

\footnotetext{
${ }^{10}$ EUR- Lex - https://eur-lex.europa.eu/legal-content/RO/ALL/?uri=CELEX\%3A52018PC0322, accesed on 17.09.2019.

${ }^{11}$ Constantin Rudnițchi, Efectele fondurilor europene asupra economiei, in RFI Romania, online edition, $22^{\text {nd }}$ of February 2016, https://www.rfi.ro/economia-reala-84918-efectele-fondurilor-europene-asupra-economiei, accessed on 24.09.2019.

12 Finantare.ro, https://www.finantare.ro/roxana-manzatu-romania-a-atras-95-miliarde-de-euro-din-fondurieuropene-rata-de-absorbtie-fiind-de-30.html, accesed on 18.09.2019.
} 
20 YEARS OF EUROPEAN FUNDS' MANAGEMENT - WHAT WE HAVE

LEARNED AND WHAT IS TO DO NEXT? A PRACTITIONER'S PERSPECTIVE

Simina, Anca, Ultima împărţire pe şest a milioanelor din Fondul de Rezervă al lui Ponta spre primării şi biserici. Cum a cheltuit Guvernul în 2013 „,bugetul paralel”, in Gandul - online edition, $12^{\text {th }}$ of December 2013, https://www.gandul.info/politica/ultima-impartire-pe-sest-amilioanelor-din-fondul-de-rezerva-al-lui-ponta-spre-primarii-si-biserici-cum-a-cheltuitguvernul-in-2013-bugetul-paralel-11756982

Staicu, Eugen, Fondul National de Garantare a Creditelor pentru IMM-uri: o solutie?, în Legestart, editie online, $27^{\text {th }}$ of February 2017, https://legestart.ro/fondul-national-degarantare-creditelor-pentru-imm-uri-o-solutiel

Vancea, Ciprian, Discutii aprinse despre cum se aloca in CJ banii pentru primarii, în Graiul Maramuresului, online edition, $8^{\text {th }}$ of August 2017, http://www.graiul.ro/2017/08/08/discutiiaprinse-despre-cum-se-aloca-cj-banii-catre-primarii/

GRAPHICS: How we did in 2007 and how are we in 2018 in terms of GDP

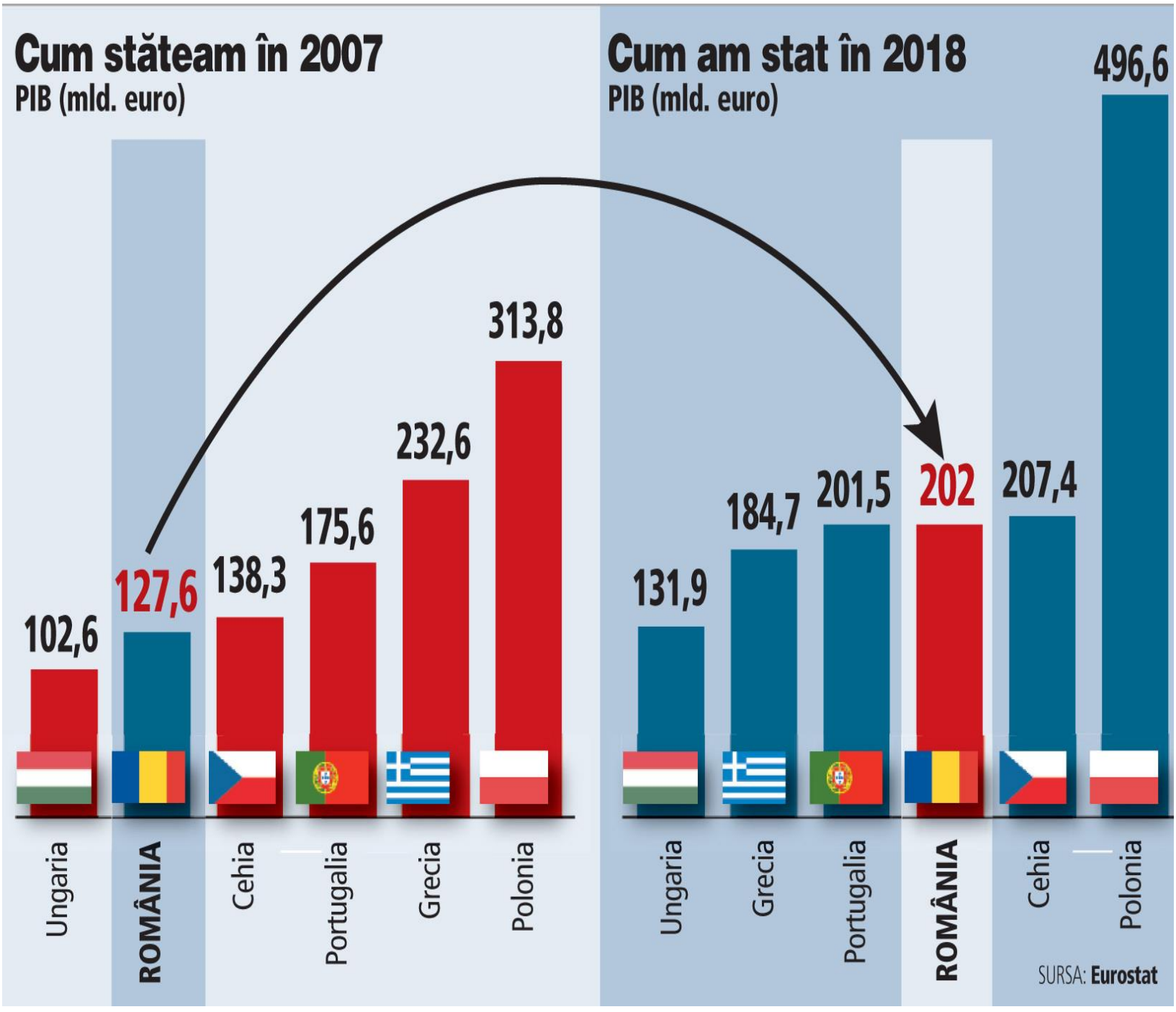

Source: Ziarul Financiar, online edition, 22nd of March 2019, https://www.zf.ro/ eveniment/romania-a-depasit-portugalia-la-pib-ul-nominal-17957768,,$\quad$ accessed on 18.09.2019. 